\title{
Dil Kardeşliği: Göçmen Öğrencilerle Etkileşimde Dilin Rolü Olabilir mi?*
}

\author{
Metin Uçar ${ }^{* *}$
}

Öz

Bu çalışma, aynı isimli bir bilimsel araştırma projesinin verilerine dayanılarak hazırlanmıştır. Proje, aralarında yeterince arkadaşlık ilişkisi olmayan, birbirlerinden uzak duran ve birbirleri hakkında önyargıları olduğu tespit edilen yerli ve göçmen ortaöğretim öğrencilerini bir araya getirmeyi hedeflemiştir. Bunun için "dil öğrenme/öğretme etkinlikleri” araç olarak kullanılmıştır. Birbirlerine ana dillerini öğretecek yerli ve göçmen öğrencilerin, birlikte vakit geçirecekleri, arkadaş olacakları ve birbirleri hakkındaki önyargılarını aşacakları varsayılmıştır. Dil etkinlikleri öncesinde, esnasında ve bittikten sonra öğrencilerin birlikte vakit geçirme ve arkadaşlık düzeyleri, anlamacı ve keşfedici bir bilimsel metodolojiye uygun olarak, "enformel sohbet tarzı görüşme" ve "gözlem" teknikleri kullanılarak anlaşılmaya çaIışılmıştır. Sonuçta öğrencilerin arkadaşlık düzeylerinin geliştiği gözlenmiştir. Kız ve erkek öğrenciler, göçmen ve Türk öğrenciler, lise ve ortaokul öğrencileri arasında ciddi farklar olduğu da anlaşılmıştır. Kızların erkeklere, göçmen öğrencilerin Türk öğrencilere, liselilerin ortaokullulara oranla daha çok gelişim sergilediği görülmüştür. Ancak genel olarak, tüm gruplarda bir ilerleme gözlendiğinden, entegrasyon için akranlarla sosyalleşmenin ve özellikle dil ile ilgili etkinliklerin ne kadar önemli olabileceği sonucuna ulaşılmıştır.

Anahtar Kelimeler: Göç, Göçmenler, Entegrasyon, Dil Eğitimi, Kültürel Karşılaşma.

The Fellowship of the Language: Could Language Play a Role in Interaction with Immigrant Students?

\section{Abstract}

Based on the data of a research project with the same title which aims at bringing together local and immigrant secondary and high school students who do not have strong friendship relations and socially distant due to the prejudices against each other. For that reason, the "language learning and teaching activities" are used as research tools in the study to achieve the goal of the project. In this regard, it is presumed in the study that local and immigrant students, teaching each other in their mother tongue will overcome the prejudices through spending time together, which will result in friendship. Students' spending time with each other and their friendship intimacy-levels (before, during, and after the language activities), were tried to be understood by using "informal conversation interview" and "observation" techniques in the sense of comprehensive and exploratory methodology. As a conclusion, a powerful interaction has been observed. Another conclusion that we reached is that there are important differences among female and male students, immigrant and Turkish students, high school and secondary school students. In this context, the girls, immigrant students, and high school students have shown more progress. Despite this difference, it can also be concluded that progress is observed in all groups. Therefore, the study concludes that socialization process among peers and language-based activities are important in achieving a full integration among different groups.

Keywords: Migration, Immigrants, Integration, Language Training, Cultural Interaction.

“Doç. Dr. | Hitit Üniversitesi İ.i.B.F. Siyaset Bilimi ve Kamu Yönetimi Bölümü metinucar@hitit.edu.tr | ORCID: 0000-0001-8816-4090 | DOI: 10.36484/liberal.876371 Liberal Düşünce Dergisi, Yıl: 26, Sayı: 101, Kış 2021, ss. 41-66. Gönderim Tarihi: 7 Şubat 2021 | Kabul Tarihi: 15 Mart 2021 


\section{Giriş̧}

Günümüzde hemen her ülkenin ilgilenmek zorunda olduğu en belirgin olgulardan biri de göçtür. Her ne kadar tarih boyunca göçün sürekliliği söz konusu olsa da göç hareketleri, günümüzdeki kadar küresel / büyük bir sorun olarak görülmemiştir. Bu sorunun büyüklüğü, ulus devletlerin her şeyi kontrol altında tutma ve planlama isteklerinin bir türevi olarak görülebilir. Zira ulus devletlerin kimlik inşa süreçlerine ve başta ekonomi olmak üzere diğer planlanan alanlara uymayan yeni gelenleri, bu kimliğin ve alanların bir parçası kılma çabası hem sorunun ne olduğunu hem de sorunun nasıl çözüleceğini özetlemektedir. Bu çerçevede ulus ile uyumlu olmayan yeni gelen bireylerin / göçmenlerin entegrasyonu (kimlik / kültür, ekonomi, eğitim, sağlık, barınma gibi alanlarda) önemli olacaktır. Her göçmen grubun hem kendi özellikleri ile hem de ev sahibi ülkenin özellikleri ile kuracağı ilişki sözü edilen entegrasyonun yönünü ve ölçüsünü belirleyecektir.

Göç denince her ne kadar "sorunlar" öncelense de aslında göçün yeni fırsatlar anlamına geldiği de göz ardı edilmemelidir. Tarihin her devrinde göçmenler (farklılıkların karşılaşması anlamında) sağladıkları etkileşim ile yerli toplumun maddi / manevi üretimine (kültürüne) yeni şeyler katmış ve ev sahibi kültürle sentezlenecek maddi / manevi değerler üretmişlerdir. Tarihte yaşanan büyük değişim ve dönüşümlerin (İslam felsefesi, Avrupa Aydınlanması ve Rönesans'ı, ABD’nin güçlü bir devlet olarak kuruluşu, Türk üniversite sisteminin Almanya'dan gelen akademisyenlerce şekillendirilmesi vb.) bu tarz kültürel karşılaşmalarla ilişkili olduğu unutulmamalıdır.

Kültürel karşılaşmalar her zaman barışçıl ve sorunsuz olmaz. Örneğin savaş, istila, işgal de kültürel karşılaşmaların örnekleridir. Tarihsel veriler düşünüldüğünde bu durumlarda bile etkileşim anlamlı olabilmiştir. Ancak günümüzdeki göçler bu tarz karşılaşmalardan çok daha farklı bir biçimde yaşanmakta, gelenler neredeyse her zaman gelinen yerin daha iyi koşullarından dolayı (ekonomi, eğitim, barış ve özgürlük ortamı gibi) geldiklerinden ellerinde şiddet araçları olmamaktadır. Hatta çoğu zaman, kendilerini kabul eden ülkelerin uygulayacakları politikalar ya da ev sahibi toplumun kendilerine karşı dışlama pratiklerine maruz kalmakta ve genellikle de kendilerini

*Bu çalışma Hitit Üniversitesi Bilimsel Araştırma Projeleri Birimi tarafından desteklenen, “Dil Kardeşliği: Göçmen Öğrencilerle Etkileşimde Dilin Rolü Olabilir mi?” adlı proje verilerine dayanılarak hazırlanmıştır. Proje Kod No: HUGAM19002.19.001

Hitit Üniversitesi BAP biriminin yanı sıra projeye; Çorum Valiliği, Konya Büyükşehir Belediyesi, Çorum Belediyesi, Karatay Belediyesi, Konya Milli Eğitim Müdürlüğü, Çorum Milli Eğitim Müdürlüğg̈ü, Konya îl Kültür Müdürlüğü ve ÖNDER (İmam Hatipliler Derneği) de yarışma ödülleri ve geziler için maddi destekler sunmuşlardır.

Projenin yürütülmesinde ve organizasyonlarda araştırmacı olarak görev alan; Prof.Dr. Fatih DUMAN, Dr. Öğr. Üyesi Hakan TURAN, Dr.Öğr.Üyesi Ertuğrul ERYÜCEL, Arş̧.Gör. Nail ELHAN, Batuhan ÇETiN, Büşra ILICA, Esma EKER, Mouhamed MOUBARAK, Selma BiÇER, Şeymanur BOLAT, Dr.Öğr.Üyesi Sevinç Soyocak ỎZALP ve Dr.Öğr.Üyesi Hatice YILDIRIM'ın önemli katkıları olmuştur kendilerine teşekkür ederim. 
savunacak araçlardan yoksun olmaktadırlar. Bu çerçeveden bakıldığında ev sahibi ülkelerin göçmen politikaları, göçten kaynaklanan olumlu etkileşimi sağlayabilir (entegrasyon / uyum) ya da engel olabilir (dışlama, gettolaştırma) gibi görünmektedir.

“Dil Kardeşliği: Göçmen Öğrencilerle Etkileşimde Dilin Rolü Olabilir mi?” Projesi göçün olumlu bir karşılaşma olduğu varsayımından hareketle hazırlanmıştır. Olumlu karşılaşmanın sağlanması için entegrasyon / uyum politikalarına ihtiyaç olduğu görülür. Uyumun daha sağlıklı olabilmesi için göçmen topluluğun ev sahibi toplumu, ev sahibi toplumun da göçmen topluluğu tanıması oldukça önemlidir. Bu çalışmada bir tanıma aracı olarak "birlikte dil öğrenme” etkili bir teknik olarak düşünülmüş ve kullanılmıştır. Birbirlerinin dillerini öğrenen öğrencilerin birbirlerini daha iyi tanıyacakları, bu durumun da entegrasyona olumlu bir yansıması olacağı ve bu kültürel karşılaşmanın her iki taraf için de olumlu sonuçlar doğuracağı varsayılmaktadır.

\section{Göçü Anlamak}

Uluslararası Göç Örgütü (IOM), Göç Terimleri Sözlüğünde (2013) göçü, “uluslararası bir sınırı geçerek veya bir devlet içinde yer değiştirmek[; s]üresi, yapısı ve nedeni ne olursa olsun insanların yer değiştirdiği nüfus hareketleridir" ${ }^{1}$ biçiminde oldukça geniş olarak tanımlar. O zaman 'mülteciler, yerinden edilmiş kişiler ve ekonomik göçmenler' de bu tanımın içine dâhil edilir. Her ne kadar günlük kullanımda göçmenler daha çok yurtdışından gelenler biçiminde algılansa ve güncel tartışmalar da önemli oranda yurtdışından gelen insanlar üzerinde yoğunlaşsa da göçmenliğin bu geniş anlamı göz ardı edilmemelidir. Bu tanım göçmenlerle empatiyi kolaylaştıracağı için özellikle vurgulanmalıdır.

Ancak her göçmenin hukuki statüsü ve durumu aynı değildir. Özellikle mültecilerin durumu oldukça hassas olduğundan onlara özel bir alan açmak gerekir. Mülteciler / sığınmacılar uluslararası hukuk tarafından bilhassa korunurlar, çünkü kendi ülkelerinden bir zorunluluktan dolayı ayrılmışlardır ve bir daha geri dönmeleri de oldukça tehlikelidir. Bu durumda kendi ülkeleri tarafından da korunamazlar hatta bazen can güvenlikleri kendi devletleri tarafından ihlal edilebilmektedir. Onun içindir ki kimin mülteci / sığınmacı olduğunun belirlenmesi de çok önemlidir (McConnell, 2016). Türkiye, kendine özgü bazı çekinceler uygulasa da uluslararası hukukun sığınmacılara ve mültecilere sağladığı haklara uymak zorundadır; ancak Suriye'den gelen yoğun göç hareketi ile birlikte "geçici koruma” statüsü olarak anılan, mültecilik ve

1 Parantez içindekiler yazara aittir. 
sığınmacılıktan farklı bir düzenlemeye gidildiği de görülür (Geçici Koruma Yönetmeliği, 2014).

Göçmenlerin hangi haklara sahip oldukları, onların ne tür bir göç yaşadıkları ile doğrudan ilişkilidir. Bu, onların hangi göçmen kategorisine dâhil edileceğini de göstereceğinden oldukça önemlidir. Tahmin edilebileceği gibi bu konuda birçok tartışma bulunmaktadır. Bu tartışmalarda göçmenlerle ilgili kullanılan çok sayıda sıfat yer alır. Bazı sıfatlar sadece sıradan bir göçün ve göçmenliğin (gönüllülüğü ima eden) değil de gerçekten de bir ölüm kalım meselesi içinde değerlendirilecek insan gruplarının varlığını da görünür kıldığından ayrıca önemsenmelidir. Onun içindir ki genel bir tanıma sığacak "göçmen" nitelemesi kullanılırken dikkatli olunmalıdır.

O zaman özel göç nedenlerini (mülteci, sığınmacı, geçici koruma vb.) göz ardı etmeden ancak tüm göçlerin de ortak özellikleri olduğunu belirtmek gerekir. Örneğin gönüllü ya da değil her göç hareketinin sorunlu olarak alg1lanabileceği yaşananlardan çıkarılabilir. Ancak gönüllü ya da değil her göç hareketinin ciddi fırsatlar barındırdığı da ortadadır. Bu çalışmamız özellikle ikinci kısmın altını çizmekte ve bu fırsatlardan birini, yabancı dil öğrenimine göçmenlerin katkısını da ortaya çıkarmaya çalışmaktadır. Ancak göçmenlere karşı son dönemlerde oluşan önyargılar, buna benzer katkıları ve gücün hemen her toplumda her zaman yaşandığını göz ardı etme eğilimleri taşımakta, göçmenleri sadece sorun olarak görmektedir.

Oysa ki göç tarihsel olarak çok gerilere gider. Hatta Kemal Karpat (2003, s. 3), semavi dinlerin Adem ve Havva kıssasının ilk göç hikayesi olarak okunabileceğine değinir. İslamiyet açısından özel bir yeri olan Hicret gibi olaylar da dinlerin göçlere yüklediği (olumlu) anlama örnek verilebilir. Yanı sıra, evrim kuramını savunanlar da insanın göç serüvenine ilk insanlar açısından çok özel bir yer ayırırlar ve göç ile insanın gelişimi / değişimi / dönüşümü arasında bağ kurarlar (Harari, 2018). Gerçekten de her ne kadar farklı görünseler de tarihe bakan hemen her göz göçlere çok özel bir yer ayırmak durumundadır. Medeniyetleri kuran hemen her topluluğun göçmen olması (Canatan, 2020, s. 22) da bu çerçevede değerlendirilebilir. Tarihte olduğu gibi günümüzde de göç oldukça önemlidir ve ciddi bir potansiyel barındırmaktadır. En gelişmiş ülkelerin (zaman zaman göçmen karşıtı politikalarla anılsalar da) göçmenlere her zaman bir kapı aralamaları da bundandir.

2019 yılı verilerine göre 272 milyon insan bugün uluslararası göçmen olarak yaşamaktadır. Üstelik bu sayının yaklaşık dörtte üçü çalışma yaşında (2064 yaş arasında) bulunmaktadır (McAuliffe ve Khadria, 2020, s. 3). 20 yaş altını hesapladığımızda bu nüfusun ne kadar dinamik olduğu da ortaya çıkmaktadır. 
Dolayısıyla ülkelerin bu üretici (maddi-manevi tüm değerler açısından) kitleye karşı duyarsız kalmaları beklenemez.

Öyle görünüyor ki göçü engellemeye çalışmak başta "insan hakları" olmak üzere birçok değeri çiğnemek anlamına da gelecektir. Onun için demokratik-medeni toplumların göçle birlikte yaşaması kaçınılmazdır. Üstelik bu birlikte yaşama isteği tarihteki birçok örneğinde olduğu gibi bugün de zararından çok yarar sağlayacak potansiyeller barındırmaktadır. En gelişmiş ülkelerin tüm iç muhalefete karşın bir yolunu bulup göçmenleri kendi sistemlerine entegre etme isteklerinin, bu gerekçe ile ilişkisi de göz ardı edilmemelidir. ${ }^{2}$

Göçmenlere yönelik dışlama mekanizması üreten düşüncenin, uzun vadede sorunları çözmek yerine yeni sorunlar ortaya çıkarması daha muhtemel görünmektedir. Göçmenleri entegre etmek yerine onları dışta bırakan ülkelerin, gettolarla / banliyölerle ${ }^{3}$ baş etmeye çalışması kolay değildir. ${ }^{4}$ Zaman zaman patlama noktasına gelen bazı sorunlar ve bu sorunlara karşı ırkçı politikaların yükselmesi, böylece sorunun daha da büyüyüp içinden çıkılamaz hale gelmesi ciddi bir tehlike arz etmektedir. Onun için entegrasyon politikalarının öncelenmesi hem ev sahibi ülkeler hem de göçmenler için en iyi çözüm olarak görünmektedir.

Gelinen toplumun mekanizmalarına katılma süreci olarak entegrasyon (Bartram, Poros ve Monforte, 2017, s. 181); “toplumsal çeşitliliği” “toplumsal kazanca” çevirmek için üretilen kavramlardan biridir. Bu amaç için uyum,

2 Almanya ve İngiltere'nin göçmenler konusundaki (vatandaşlığa geçiş, ırkçılıkla mücadele, ayrımcılığa karşı yasal düzenleme, işgücü piyasasında pozitif ayrımcılık, çokkültürlülük politikaları gibi) çabaları (Lacroix, 2010, s. 4 vd.) bu çerçevede okunabilir.

3 Kentte dışlanan grupların yerleştiği mekânları anlatmak için birçok kavram geliştirilmiştir. Slum, getto, varoş, banliyö bunlar arasındadır. Genel anlamda aynı anlama gelseler de bazı sosyal bilimciler aralarındaki fark konusunda ısrarcı davranır (Çetin, 2012, s. 166). Bu çalışmada konumuz bu olmadığı için bu farklar üzerinde durma gereği duyulmamıştır ancak konumuz açısından meseleyi ortaya koyacak getto ve banliyö için kısa bir açıklama yapma gereği duyulmuştur:

Getto, belli bir kültürel grubun yoğunlaştığı mekânı anlatır. Bu mekân hâkim kültürden farklııklar gösterir. Bir açıdan, kültürel azınlığın kendisini koruması için bir sığınak sağlar, ancak diğer açıdan hâkim kültürün dışlama pratiklerinin bir sonucudur. Yabancı düşmanlığı ya da göçmen karşıtlığı gibi ev sahibi ülke yurttaşlarının verdiği tepkiler, birçok kültürel azınlık için gettolaşmayı adeta zorunlu kılmaktadır. Gettonun ne olduğuna dair bkz. (Adıgüzel, 2019, s. 157 vd.; Çetin, 2012, s. 170 vd.).

"Banliyö" Fransızca kökenli bir kavramdır ve "dış mahalleleri” anlatır. Ancak Amerika ve Avrupa'da birbirine zıt iki farklı kullanımı olmuştur. İlkinde gelir durumu iyi olan insanların kentten uzak yaşadıkları mahalleleri anlatırken ikincisinde fabrikalara yakın işçi konutları için kullanılması daha belirgin olmuştur. Zamanla işçilerin yaşadığı yerler anlamını aşan ve "getto" kavramına benzer şekilde dışlanmışlıkla, yoksullukla, kötü yaşama koşulları ile hatta isyanla anılan mahalleler anlamına gelmiştir. Bizim kullanımımız da daha çok bu anlamı ile ilişkilidir. Banliyö hakkında farklı anlamlar ve kullanımlar için bkz. (Çetin, 2012, s. 178 vd.; Khayati, 2009, s. 173 vd.;

4 Bu konuda Fransa ilginç bir deneyim yaşamaktadır. Fransa'nın göçmenlere yönelik politikalarını dışlayıcı bulan çok sayıda düşünce olduğunu hatırlatmak gerekir. Özellikle getto/banliyö kaynaklı, Fransa'da zaman zaman çatışmalara varan olayların çıkması göçmenlere karşı dışlayıcılığı gündeme taşımaktadır. Banliyö kaynaklı olaylar Fransa'da çok ciddi krizlere neden olmakta, ancak öyle görünüyor ki göçmen karşıtlığı bu krizi daha da derinleştirmektedir. (Banliyö olaylarına da değinerek Fransa'nın entegrasyon politikalarını değerlendiren bir çalışma için bkz. Yardım, 2017). 
sosyal uyum, içerme, kültürleşme, çokkültürcülük, kültürlerarasıcılık, hoşgörü, tahammül, tolerans gibi daha birçok kavramdan da söz edilebilir (Erdoğan, 2020, s. 12). Bu listenin oluşturulmasında kuşkusuz farklı bakış açıları ve politikalar etkili olmuştur ancak asıl amacın farklılıklarla birlikte uyum ve barış içinde yaşamak olduğu gözden uzak tutulmamalıdır. Biz burada, ciddi eleştirilerin de odağında olmasına karşın, daha yaygın bir kullanıma sahip olan entegrasyon kavramını ${ }^{5}$ "toplumsal çeşitliliği toplumsal kazanca” çevirmenin bir yolu olarak düşünecek ve kullanmaya devam edeceğiz.

Göçün “zararından” çok “gerekliliğini” algılayan birçok ülke, kendi göç politikalarını da değiştirmiştir. Bu açıdan bakıldığında (pragmatik davranarak) göçe karşı olmayı değil de göçü yönetmeyi, göçün bitirilmesini değil de kontrollünü sağlamayı amaçlayan adımlar atılmaktadır. En anlamlı politika "daha kısıtlayıcı değil daha seçici” olmayı zorunlu kılmaktadır. Bu politika sadece dişarıdan göç almayla sınırlı da değildir; mevcut göçmenleri de bu amaca yönlendirmenin yolunu bulmaya çalışmaktadır. İşte entegrasyon tam da burada anlam bulur (Lacroix, 2010, s. 4).

Göçün olumlu sonucu, "toplumsal çeşitliliği toplumsal kazanca” dönüştüren, sadece ev sahibi ülkenin rızasını ve varlığını sürdürmesini önceleyen değil ayrıca göçmenlerin de varlığını, kendi kimliklerini koruyarak garanti altına alacak bir entegrasyon süreci ile olabilir. O zaman göçmenlerin "sorunlarla” ve "yük olmakla” değil de üretkenlikleri ile öne çıtıkları görülecektir. ${ }^{6}$

Gerçekten de tarih boyunca “iyi yönetilen göç”, küresel çapta gelişmeyi tetiklemekte ve çok önemli firsatlar sunmaktadır. Göçmenler, sadece ucuz işgücü ile değil, girişimci, yenilikçi ve risk alabilen insanlar olarak da geldikleri topluma ciddi katkılar sunarlar. Hatta yaş ortalaması çok yüksek olan birçok Avrupa ülkesi için "gelecekte emeklilik maaşını ödeyecek" insanlar olarak bile düşünülebilirler.7 Yanı sıra farklı kültürlerden gelmenin yeni fikirler üretme

5 Entegrasyonla ilgili tartışmalar için bkz. (Bartram, Poros ve Monforte, 2017,s. 181 vd; Erdoğan, 2020, s. 12 vd.; Göksel, 2019, s. 16 vd.).

6 Madeline Albright (Çekostlavakya'dan göç etmek zorunda kalmıştır), Albert Einstein (Almanya'dan göç etmek zorunda kalmıştır), Marie Curie (Polonya'dan Fransa'ya gitmiştir), Nikola Tesla (Balkanlardan Amerika'ya göçmüştür), Freddie Mercury (Tanzanya'da doğmuştur), Steve Jobs (babası Lübnan'dan kaçmak zorunda kalan bir Suriyelidir) ve Zinedine Zidane (babası Cezayir doğumludur) gibi önemli insanların ya kendileri ya da aileleri göç eden dolayısıyla göçmen insanlardır. Kuşkusuz bu liste her ülke için ayrı ayrı ciltlerce kitap yazacak kadar göçmenlerle doldurulabilir.

Bu listede bulunan göçmenlerin hayatlarının en azından belli bir dönemi çok zor şartlar altında geçmiştir. Bu örneklerdeki insanlar Amerika Birleşik Devletleri'ne, Fransa'ya ve İngiltere'ye göçmüş̧ ve zor hayat şartlarına karşın, geldikleri topluma ciddi katkıları olmuştur. Ancak bu katkılar için güven içinde yaşama alanlarının açılması ve bu insanlara fırsat verilmesi gerektiği açıktır. Bu ve benzer örnekler için bkz. (d'Oultremont ve Martin, 2015, s. 10; Harward, 2016; Nawyn, 2016; Saboohi, 2018, s. 564-65).

7 Göçmenlerin ekonomiye etkileri konusunda çok farklı değerlendirmeler yapılabilir. Örneğin ev sahipleri kiraların artışını fırsat, kiracılar ise risk olarak düşünebilirler; iş sahipleri ucuz emeği 
potansiyeli de göz ardı edilmemelidir. Bunun alternatifi ise duvarlar inşa etmek, bariyerler kurmak, gözaltı merkezleri açmak, göçmenleri geldikleri yere zorla geri göndermek ve her an göçmenlerden geleceği varsayılan tehlikelere karşı korku ile yaşamaktır (d'Oultremont ve Martin, 2015, s. 10-11). Ayrıca göç yolunda hayatlarını tehlikeye atacak kadar ciddi badireleri göze alan insanların, yaşadıkları ülkedeki durumları bir insanlık dramını anlatır ki buna karşı sert tedbirler almak da insan haklarını ihlal etmek anlamına gelecektir. Görüldüğü gibi göçe karşı çıkmak oldukça maliyetli ve kimseye fayda sağlamayan bir politikadır.

Göçün yararları (ya da zararları) konusunda daha çok şey söylenebilir ancak "göç olsun mu olmasın mı" meselesinden bağımsız olarak göçün bir veri olduğunu, hem göçmenler hem de ev sahibi ülkeler açısından çoğu zaman bir zorunluluk olduğunu göz ardı etmemek lazım. Bu zorunlu birlikteliği (bir çözüm bulunana dek) en yararlı şekilde geçirmeye odaklanmak, kuşkusuz en akıllıca yol olacaktır. Örneğin göçmen öğrencilerle aynı sıraları paylaşmak bir veri ise o zaman bu durumu fırsata çevirmek, üstelik hem göçmen hem de ev sahibi ülke öğrencileri için faydalı olacak bir etkinliğe çevirmek (dil öğrenme gibi), yapılabilecek en güzel işlerden biri olacaktır. "Dil Kardeşliği” tam da bu tespitle hareket etmekte ve karşılıklı bir faydayı, uygulamalı olarak göstermeye çalışmaktadır.

\section{Alan Araştırması ve Dil Kardeşliği Uygulaması: Yöntem ve Projenin Uygulanması}

\section{Yöntem}

Nitel araştırmalar ve özellikle görüşme tekniği, daha önce görülmeyen, anlaşılmayan ve araştırmacı tarafından düşünülmeyen birçok konunun da su yüzüne

fırsat olarak görürken, işçiler bu konuyu çok farklı değerlendirebilirler. İşsizlik ile göçmenlerin geliş̧i arasında her zaman bağ kurulabilir ama göçmenlerin gerçekten "zayıf halka" oldukları için mi bu tarz suçlamalara maruz kaldığı yoksa gerçekten de olgusal düzeyde bunun bir karşıı̆̆ı olup olmadığı farklı tartışmalara konu olabilir. Zira göçmenlerin gelişi ayrıca yeni iş alanları açmak anlamına da gelmektedir. Göçmenlerle ilgili değerlendirmelerin daha çok algılar ile ilişkili olduğu bunun olgusal boyutta değerlendirilmesi ile çok farklı sonuçlara ulaşılabileceği söylenebilir. Suriyelilerin ekonomiye etkisini olumlu ve olumsuz yönleri üzerinden değerlendiren ve anket sonuçlarına dayanan bir çalışma için bkz. (ORSAM, 2015, s. 17 vd.)

Türkiye'de göçten en çok etkilenen illerden biri olan Kilis'te esnaflarla yapılan bir alan araştırmasında Suriyelilerin hem tüketici olarak hem de üretici olarak Kilis ekonomisine ciddi katkılar sağladıkları sonucu çıkmıştır (Paksoy ve Özgüven, 2017). Suriyeli girişimcilerin Türkiye'ye ekonomisine etkisini girişimcilik modelleri açısından anlatan bir çalışma (Kaplan ve Bedük, 2019, s. 236 vd.) meselenin katkı boyutunu öne çıkarmaktadır. Ayrıca başta Mersin ve Gaziantep ticaret verilerinin gösterdiği sonuçlar olmak üzere birçok veri, Suriyeli işadamlarının ciddi katkılar sağladığını göstermektedir. Bu konuda özellikle Halepli işadamlarının ticaret bağlantıları da dâhil olmak üzere birçok birikimini geldikleri yere taşıdıkları anlaşılmaktadır (ORSAM, 2015, s. 18). 
çıkmasını sağlayacak potansiyele sahiptir. Zira görüşme; dinamik, esnek, yeni bilgiye açık yani araştırmacının araştırmaya başlarken kafasından geçen konularla sınırlı olmayan bir tekniktir. Bu teknik, belli davranış kalıplarının yasalarını / düzenliliklerini bulmak yerine sosyal yaşamın farklı yönlerini betimlemeyi daha anlamlı bulur. Onun için nedensellikleri bulmayı amaçlamaz; bunun yerine kişilerin anlam dünyalarını ve deneyimlerini ayrıntılandırmaya çalışır (Skinner, 2012, s. 10). Bu çerçevede Chicago Okulu temsilcilerince geliştirilen, günlük yaşamın doğallığını önemseyen "yapılandırılmamış teknikler” bazı araştırmacılar tarafından öne çıkarılmıştır (Mayring, 2011, s. 15).

Yapılacak araştırmanın niteliğine göre yapılandırılmamış teknikler farklılık gösterebilir. Bu anlamda yapılandırılmamış görüşme tekniklerini yönlendirici olmayan görüşme, odak grup görüşmesi ve enformel sohbet tarzı görüşme biçiminde üçe ayırmak mümkündür. Görüşme teknikleri bir yelpaze gibi düşünülürse bir uçta "tam yapılandırılmış görüşme" diğer uçta ise "enformel sohbet tarzı görüşme” bulunur. Yani görüşme teknikleri içinde "en açık uçlu” olanı enformel görüşmedir. Esnek yapısı ile anlamaya ve keşfetmeye odaklanan alan araştırmalarına çok uygundur. ${ }^{8}$ Görüşülen kişilere bir görüşme yapıldığı söylenebilir ya da kişiler bunun farkında olmadan da görüşmenin bir parçası olabilirler. ${ }^{9}$ Görüşmeler, anında cihazlarla ya da not tutularak kayıt altına alınabileceğ ${ }^{10}$ gibi görüşme bittikten sonra da araştırmaCl tarafından işlenebilir (Gray, 2004: 217). Enformel görüşmeler için "gözlem verileri” yardımcı ve tamamlayıcı olarak kullanılır (Jamshed, 2014: 88) ki bu da araştırma verilerinin gücünü arttıracaktır.

Özellikle daha önce araştırma yapılmamış alanlarda yapılandırılmamış teknikler (gözlem ve görüşme) daha yararlı olduğundan bu çalışmada da “enformel sohbet tarzı görüşme" ve onu destekleyecek mahiyette "gözlem tekniği” tercih edilmiştir. Enformel sohbet tarzı görüşme tekniğini kullananlar, araştırma alanını anlamak için ortama dâhil olurlar, hem yaptıkları yapılandırılmamış sohbetler hem de gözlemlerle verilere ulaşırlar. ${ }^{11} \mathrm{Bu}$

8 Şüphesiz bu tekniğin avantajları olduğu gibi özellikle "esnek” yapısından dolayı bazı dezavantajları da vardır. Enformel görüşme tekniğinin avantajları ve dezavantajları için bkz. (Moeller vd, 1980: 180-181).

9 Kişilerin farkında olmaması ayrıca etik tartışmaları da beraberinde getirecektir. Ayrıca bu tarz görüşmelerde kişilik haklarına dikkat etme ve görüşülen kişileri rencide etmeme konusunda çok dikkat etmek gerekir. Enformel görüşme tekniği ile ilgili etik sorunlar için bkz. (Moeller vd, 1980: 180-181). Görüşme ve gözlem tekniğine dair daha genel etik sorunlar için bkz. (Gray, 2004: 235236; 258-259).

10 Görüşülen kişinin bilgisi varsa kayıt altına almak daha kolay olacaktır. Ancak bazı durumlarda, görüşülen kişinin kendisini daha rahat ifade etmesi ya da dikkatlerin dağılmaması için görüşme sonuçlarının ve gözlem notlarının araştırmacı tarafından daha sonra tutulması yerinde olacaktır (Emerson, Fretz ve Shaw, 2008: 20 vd.).

11 Enformel görüşme tekniği çok farklı alanlarda kullanılabilir. Örneğin sıtma ile ilgili alanda çalışan doktorların çalışma ortamını anlamak ve onların ne düşündüklerini bulmak için bu tekniğe başvuran bir çalışma için bkz. (Canavati vd., 2017: 3). 
tekniklerin kullanılmasının bir başka gerekçesi de lise ve ortaokul öğrencileri ile bu araştırmanın yapılıyor olmasıdır. Zira enformel görüşme ve gözlem, öğrencilerin dünyalarına müdahil olmadan ama onlarla aynı ortamda bulunarak veri toplamanın en uygun yolu olarak düşünülmüştür. ${ }^{12}$

Görüşmeler temel olarak öğrencilerle yapılmış ancak öğretmenler ve yöneticilerin de konu hakkındaki düşüncelerine başvurulmuştur. Gözlemler ise öğrencilerin doğal ortamında, özellikle göçmen öğrenciler ile Türk öğrencilerin ilişkileri düşünülerek gerçekleştirilmiştir. Görüşme ve gözlemler temel olarak, dil etkinlikleri sayesinde birlikte vakit geçiren çocuklar arasında "önyargıların azalıp azalmadığı" ve buna bağlı olarak "arkadaşlık ilişkilerinin artıp atmadığını” anlamaya yönelik olmuştur.

Böyle bir dil etkinliği her şeyden önce öğrencilere eşit ilişkiler geliştirebilecekleri bir zemin hazırlamaktadır. Bu ilişki biçimi göçmen-yerli, dil bilen-dil bilmeyen, öğrenen-öğreten, dersleri iyi-dersleri kötü olan veya sınıfta arka-ön sırada oturan ayrımlarını ortadan kaldırmakta, öğrencilerin sadece birer arkadaş ve birbirlerine karşılıklı bir şeyler öğreten kişiler olarak konumlanmalarını sağlamaktadır. Eşitler arası ilişkiler, insanların birbirlerini anlamaları bakımından çok daha olumlu sonuçlar vermektedir. ${ }^{13}$

Görüşme ve gözlem gibi nitel araştırmaların "kültürel karşılaşmalar” gibi konularda büyük katkı sağlayacağı söylenebilir. Farklı dillerin karşılaşmasını önemseyen “Dil Kardeşliği Projesi”, temelde dil öğrenmeye merkeze alan bir dizi etkinlikten oluşmuştur. “Dil uygulamaları” öncesinde göçmen öğrenciler ile Türk öğrencilere dil öğrenme istekleri ve birbirlerinden dil öğrenmeye nasıl baktıkları konusunda, keşfedici bir tarzı besleyecek şekilde "enformel sohbet tarzı görüşmelerin” yapılması bundan dolayı anlamlı olmuştur. Dil etkinlikleri öncesinde ve etkinlikler sürerken, yardımcı bir araç olarak "gözlem” tekniğine de başvurulması, araştırma başlangıcında elde edilen verilerin değişiminin izlenmesinde projenin amacını beslemiştir.

Projenin uygulama aşaması Çorum ilinin Merkez ilçesinde gerçekleştirilmiştir. Araştırma mekânımız olan Çorum 15 binin üzerinde yabancı uyruklu göçmen barındırmaktadır. Çorum'da yaşayan yabancıların çok büyük

12 Şüphesiz literatüre bakıldığında lise ve ortaokul düzeyindeki öğrencilerle "görüşme" ve "gözlem" tekniklerinin, yapılandırımamış farklı formalarının da kullanılabildiği görülür. Derinlemesine görüşme ve gözlem tekniği ile göçmen çocuklarla yapılan örnek araştırmalar için bkz. (Aslan A., 2020; Atasü Topçuoğlu, 2015).

13 Konya'da yapılan bir araştırma, Suriyelilerin işlettiği restoranlara giden Türklerin Suriyelilere karşı önyargılarının daha az olduğunu ortaya çıkarmıştır. Iletişimin önemini anlatan bu çalışma, farklı karşılaşmaların türü ile önyargılar arasındaki ilişkiye de değinmektedir (bkz. Akın, Şeçim ve Akın, 2020). Böylece (ilişkinin türüne göre bazen tehdit olarak algılanması söz konusu olsa da) daha eşit karşılaşmaların (aynı mekânda aynı işlev için bulunmak, söz gelimi yemek için restoranda bulunmak, yan masada oturmak) önyargıları azaltıcı bir etkiye sahip olmaktadır. 
bir kısmını Iraklılar oluşturmaktadır (Çorum Post, 2019). Çorum'da (6 Ocak 2021 verilerine göre) yaklaşık olarak 3000 civarında Suriyelinin geçici koruma statüsünde (Göç İdaresi, 2021) bulunmasına karşın yaygın olarak, tüm yabancıların (hatta Orta Asyalı Türklerin ve Afrikalı öğrencilerin de) Suriyeli olduğuna dair bir önyargi ${ }^{14}$ görülmektedir.

Göçmen öğrencilerin sayısal çokluğu ve Arapçanın ders müfredatında bulunması dikkate alınarak bu çalışma, imam hatip eğitimi veren iki lise ve iki ortaokul olmak üzere toplam dört okulda ${ }^{15}$ gerçekleştirilmiştir. Etkinliklere 69'u lise düzeyinde, 132'si ortaokul düzeyinde olmak üzere toplam 201 öğrenci katılmıştır. ${ }^{16}$ Çalışmaya katılan göçmen öğrencilerin neredeyse tamamının Iraklılardan oluştuğunu (çok az Suriyeli ve Afganistanlı öğrenci olduğunu) belirtmekte yarar vardır. Bunun nedeni özel bir seçimden ziyade, okullarda okuyan yabancı öğrencilerin hemen hepsinin Iraklılardan oluşmasındır.

\section{Araştırma Süreci}

Yöntem belirlendikten sonra valilik ve Çorum İl Milli Eğitim Müdürlüğü’nden etkinlikler için resmi izinler alınmıştır. İzin alma sürecinde proje ekibi kurulmuştur. Proje ekibi, organizasyonu sağlayacak öğretmenler ve alandan verileri toplayacak yüksek lisans öğrencilerinden seçilmiştir. Yüksek lisans öğrencileri, sosyal bilimlerde araştırma yöntemleri dersleri alan öğrencilerden seçilmişlerdir. Bu öğrencilere araştırmada kullanılan teknikler hakkında bilgi verilmiş, bazı örnekler üzerinden uygulamalar açıklanmıştır. Özellikle gençlerle çalışmanın hassasiyeti üzerinde durulmuş, görüşme ve gözlemlerde müdahil olmaktan çok ortamı anlamaya ve uyum göstermeye odaklanmaları istenmiştir. Gençlerin oyunlarına katılmaları ve onlarla birlikte vakit geçirmelerinin bu çerçevede olmasına dikkat etmeleri konusunda uyarılmışlardır.

Ekip kurulduktan sonra Çorum İl Milli Eğitim Müdürlüğü’nün ilgili birimleri, ilgili okul müdürlükleri ve bazı öğretmenler ile görüşülmüş, onlara planlanan çalışmalar konusunda bilgiler verilmiş ve katkıları istenmiştir. Özellikle okul idarelerinden çok ciddi destekler alınmış ve bazı gönüllü öğretmenler ile de birlikte çalışılmıştır.

14 Bu tespitler; bu araştırmadan bağımsız olarak şahit olunan olaylar ve Çorum'da bulunan yabancı üniversite öğrencileri ile yapılan sohbetler esnasında dile getirilenler çerçevesinde yapılmaktadır. Ancak daha sonra değinileceği gibi projenin yürütüldüğü okullarda çok az Şuriyeli öğrenci olmasına karşın, öğretmenlerin ve Türk öğrencilerin Iraklı öğrencileri "Suriyeli” olarak nitelendirmeleri de bu tespiti desteklemektedir.

15 Bu dört okul şunlardır: Çorum Belediyesi Prof. Dr. Hayreddin Karaman Anadolu Lisesi, Şehit Erol Olçok Anadolu İmam Hatip Lisesi, Kerebi Gazi İmam Hatip Ortaokulu ve Yıldırım Beyazıt İmam Hatip Ortaokulu.

16 Türkçe bilmeyen ya da Türkçesi iyi olmayan göçmen öğrencilerle iletişim ve görüşmeler, Türkçeyi iyi bilen gönüllü liseli ve üniversiteli göçmen öğrenciler tarafından sağlanmıştır. 
Öncelikle öğrencilere, “Dil Kardeşliği” ile ilgili bir araştırma yapıldığı ve bu kapsamda etkinlikler yapılacağı duyurulmuştur. Etkinliğe katılmak isteyen öğrencilerin ailelerinden izin almaları istenmiş, bunun için ailelere araştırma ve etkinlikleri anlatan katılım formu gönderilmiştir. Katılım formunu velilerine imzalatan 201 öğrenci, yapılacak “Dil Kardeşliği” etkinliğine dâhil edilmiştir.

2019 yılının Nisan ayında başlatılan projenin uygulama aşaması, liselerde Nisan'ın son haftası ile Haziran'ın ilk haftasını kapsayacak şekilde 6 hafta, ortaokullarda ise Mayıs'ın ikinci haftası ile Haziran'ın ilk haftasını kapsayacak şekilde 4 hafta sürmüştür.

Etkinlikler, öğrenciler arasındaki etkileşimi arttırmayı amaç edinen üç temel noktada toplanmıştır; (1) dil öğrenme etkinliği, (2) dilin önemine binaen okul ortamında yapılan seminer ve söyleşiler ve (3) okul dışında yapılan yarışma ve gezi. Görüldüğü gibi 1 . ve 3. etkinlikler doğrudan etkileşimi arttırırken, 2. etkinlik, etkinliklerin ciddiyetini anlatarak ve motivasyonu artırarak etkileşime dolaylı bir şekilde hizmet etmiştir.

1. Dil Öğrenme Etkinliği: Gönüllü öğrenciler dil düzeylerine göre (iki göçmen, iki Türk öğrenci olacak şekilde) gruplara ayrılmıştır. ${ }^{17}$ En fazla gelişim gösterecek öğrencilere ödüller verileceği duyurulmuştur. Dört kişiden oluşan öğrenci gruplarının birbirleri ile kaynaşmaları için bir "grup ismi" bulmaları ve teneffüslerde bir araya gelerek birbirlerine kendi dillerini öğretmeleri istenmiştir. Dil öğrenme konusunda yol gösterici olması için, her hafta Türkçe-Arapça temel cümleleri içeren A4 kâğıdı büyüklüğünde bir materyal dağıtılmıştır. Bu materyalin çoğaltılmaması ama her bir araya gelişten sonra bir başkasına verilmesi tembih edilmiştir, böylece bir araya gelmek için gerekçeler üretilmiştir. Aynı şekilde bir araya gelinmesi amacıyla her grup için; liselerde bir yüksek lisans öğrencisi araştırmac1, ortaokullarda ise bir gönüllü öğretmen ${ }^{18}$ görevlendirilmiştir. Liselerde araştırmacılar haftada iki gün öğle arasında kendilerine verilen grubu ziyaret etmişler ve dil çalışmalarını bizzat gözlemlemişlerdir. Ortaokullardaki öğretmenlerden de haftada bir gün öğrencilerin bir araya gelip gelmediklerini öğrenmeleri istenmiş ve proje ekibi ile paylaşmaları rica edilmiştir.

2. Yabancı dil öğrenmenin önemine binaen okul ortamında yapılan söyleşiler: Proje ekibi, proje kesinleştikten hemen sonra öğrencileri dil öğrenmeye teşvik etmek için söyleşiler yapmıştır. Arapça ve Türkçeyi iyi öğrenmenin

17 Lise düzeyinde beş kişilik bir grup dışında tüm grupların 4 kişiden oluşmasına özen gösterilmiştir. Ancak ortaokul düzeyinde grupların çoğu dört kişiden oluşsa da tüm gruplar için $2+2$ sistemini uygulamak bazen mümkün olmamıştır. Bazı öğrencilerin yaşlarının küçük olması ve ısrarlı bir biçimde kendi seçtikleri gruplara dâhil olma istekleri, heveslerini kırmamak adına hoş karşılanmıştır, onun için ortaokullarda $2+3 ; 3+2$ biçiminde gruplara da izin verilmiştir.

18 Gönüllü öğretmen talebimiz okul idareleri tarafından olumlu karşılanmış, bunun için Proje Ekibi tarafından öğretmenler ile toplantılar yapılmış ve proje anlatılmıştır. Daha sonra gönüllü olan öğretmenlerin bize ulaşmaları ya da okul idaresi ile temasa geçmeleri rica edilmiştir. Ancak gruplar oluştuktan sonra bazı öğretmenlerin etkinliklerle ilgilenmedikleri görülmüş bu da gönüllülük konusunda istenen amaca ulaşılamadığını göstermiştir. 
kendilerine ne gibi kapılar açacağı özellikle vurgulanmış ama sadece bunlarla yetinilmemiş ve öğrenilen her bir dilin yeni fırsatlar sunacağı kamuoyu tarafından bilinen örnek kişiler üzerinden anlatılmıştır. Öğrencilerin hem dil öğrenimi hem de proje hakkındaki sorularına da cevap verilmiştir. Proje ilerlemeye başladıktan sonra Çorum Valisi Mustafa Çiftçi ile Çorum Belediye Başkanı Dr. Halil İbrahim Aşgın'ın etkinliğe katılan öğrenciler ile “dilin önemi” konusunda söyleşi yapmaları sağlanmıştır. Bu söyleşiler, öğrenci motivasyonunu arttırdığ1 gibi okul yöneticilerinin ve velilerin de projeye zaten var olan desteklerinin sürmesini ama daha da önemlisi, işin ciddiyetini anlatmıştır. Yanı sıra ziyaretlerin basında ve sosyal medyada yer alması ile projenin bilinirliğinin artacağı ve kamuoyunda entegrasyon konusunda bir bilinç oluşmasına da katkı sunacağı düşünülmüştür.

3. Okul dışında yapılan yarışma ve gezi: Motivasyonu sağlamak için etkinlik sonunda başarılı olanlara hediyeler verileceği ve etkinliklere katılıp sonuna kadar devam eden her öğrencinin de Konya'ya yapılacak bir geziye götürüleceği duyurulmuştur. Etkinliğe devam oldukça fazla olduğundan öncelikle okullarda bir yazılı eleme sınavı yapılmış, dereceye giren öğrenciler diğer okullardan dereceye girenlerle birlikte bir sözlü yarışmaya tabi tutulmuştur. Lise ve ortaokul kategorileri ile Arapça ve Türkçe kategorileri farklılaştırılarak dereceye girenlere ödüller verilmiştir.

\section{Uygulama Öncesi ve Uygulama Sürecindeki Tespitler}

Göç çalışmalarında elde edilen sorunlar/tespitler ile bizim elde ettiğimiz veriler birlikte düşünüldüğünde, konunun karmaşıklığı ve hassaslığı çok daha iyi bir biçimde ortaya çıkmaktadır. Ayrıca projenin bağlamını anlamayı sağlayacak bu sorunlar/tespitler özellikle eğitim alanına yoğunlaşmaktadır.

1. Akranlar tarafından dışlanmak: Öğrencilere projeyi anlatmak için sınıflara gidildiğinde göçmen öğrencilerin çok büyük bir kısmının yalnız ya da diğer göçmenlerle birlikte oturduğu ve genellikle koridor tarafı ve/veya arka kısımda oldukları görülmüş̧ür. Göçmen öğrencilerden azımsanmayacak bir kısmının hiçbir Türk arkadaşının olmadığı ve bazılarının ise hiçbir Türk ile sohbet etmediklerini söylemeleri dikkat çekici bir durum olarak not edilmiştir. Aynı şekilde Türk öğrenciler de göçmen arkadaşlarının hiç olmadığını ya da çok az olduğunu ifade etmişlerdir. Türk öğrencilerin göçmen öğrenciler hakkında bilgilerinin olmadığı, neredeyse tamamı Iraklı olan arkadaşlarını daha çok Suriyeli olarak düşündükleri de anlaşılmıştır. Arkadaş olarak gösterilen kişilerin de genellikle sosyal yönü kuvvetli olan, derslerinde başarılı ve iyi Türkçe konuşan birkaç göçmen öğrenci olduğu görülmüştür.

Kız öğrenciler erkek öğrencilere oranla daha iyi arkadaşlıklar kurabilmişler ancak bu da sadece sosyal yönü güçlü çok az öğrenci ile sınırlı kalmıştır. 
Aynı şekilde ortaokulların da liselilerle karşılaştırıldığında (her ne kadar yeterli olmasa da) arkadaşlık kurma konusunda daha iyi oldukları gözlenmiştir. Özellikle Türkçeleri iyi olan kız göçmen öğrencilerin (2 çarpıcı örnekte kızların Türkçeyi çok düzgün konuştukları ve derslerinin de oldukça iyi olduğu, hatta Türk arkadaşlarına dersler konusunda yardımcı oldukları saptanmıştır) diğer gruplarda olmayan bir uyumları görülmüştür.

Göçmenlere yönelik önyargılar arkadaşlık kurmada ciddi bir engel olarak görülmüştür. ${ }^{19}$ Liseli erkek öğrencilerde daha belirgin bir biçimde olsa da bazı ortaokul öğrencilerinde de açığa çıkan bu durum; "savaştan kaçmak", "korkak olmak", "vatanlarını terk etmek” gibi temalarla anlatılmıştır. Bazı Türk öğrencilerin de (diğer Türk öğrencileri eleştirerek “onlar/göçmenler için savaştan kaçan kişiler, korkaklar, vatanlarını bırakanlar... diyorlar” biçiminde) dile getirdiği bu konuları özellikle göçmen öğrenciler, kendilerine yönelik bir "dışlama söylemi" olarak sıklıkla ifade etmişlerdir. Göçmen öğrencilerin bu konuda kendilerini savunmak zorunda hissettikleri gözlenmiştir. Örneğin “neden Türk arkadaşınız yok?” sorusu sorulduğunda birçok göçmen öğrencinin "bizi vatan haini, korkak görüyorlar" benzeri beyanları olmuştur. Bu da göçmen öğrencilerde Türk öğrencilerin kendilerini yeterince anlayamadıkları düşüncesini beslemektedir. ${ }^{20}$

Türk öğrencilerin sıklıkla göçmenleri “kavgacı/geçimsiz” olarak tanımlamaları da arkadaşlık kurmada bir engel olarak görülmüştür. Kültürel farklılık ve dil bilmemenin beslediği bu durum, şahit olunan bazı olaylarda da ortaya çıkmıştır. Örneğin araştırmacıların ziyaretleri esnasında, ekiplerin birinde göçmen bir öğrencinin arkadaşları ile küstüğü fark edilmiştir. Kendisine neden küstüğü sorulduğunda, arkadaşları ile konuşurken, "kendisine hakaret edildiğini” söylemiştir. Konuşmanın niteliği öğrenildiğinde aslında ortada hakaret içermeyen bir sohbet olduğu anlaşılmıştır. Türkçeyi iyi bilmeyen bu öğrencinin hakaret içermeyen bir sohbeti böyle algılaması, dil bilmenin önemini bir kez daha göstermiştir.

19 Suriyeli öğrencilerin akranları tarafından dışlandığına dair bazı alan çalışmalarından da söz edilebilir. Öğretmenlerin gözlemlerine dayanan, Suriyelilerin akranları tarafından ötekileştirilmesine dair bazı anlatıları "Etiketlenme" ve "Ötekileştirilme” alt başıاıları ile anlatan bir çalışma için bkz. (Altuntaş, 2018, s. 480vd.).

Göçmen Afgan öğrencilerle yapılan görüşmelere dayanan bir yüksek lisans çalışmasında ise öğrencilerin bir kısmının ilk geldiklerinde (dil bilmedikleri dönemde) dışlandıklarını ama Türkçe öğrenmeye başladıktan sonra bu olumsuzluğun kalktığını; bazıları dışlanmadıklarını ve bazıları ise dil öğrendikten sonra da dışlandıklarını söylemişlerdir (Doğan, 2019, s. 70 vd.).

20 Samsun'un Çarşamba ilçesinde Suriyeli öğrencilerle yapılan bir çalışmada, arkadaşlık kurmada bir sorun olmadığı aksine iyi arkadaşıkların kurulabildiği ama önyargıların da olduğu sonucuna ulaşılmıştır (Aslan A., 2020, s. 49-50). 
İkinci bir olay da (iyi Türkçe bilmeyen) bir göçmen öğrenciye bir Türk öğrencinin (şaka yaptığını düşündüğü) "şu arkadaş sana küfür ediyor” biçimdeki ifadesi ve sonrasında Arapça bilmeyen Türk öğrenci ile Türkçe bilmeyen göçmen öğrencinin birbirini ikna edememesi sonucunda yaşanan anlaşmazlıktır. ${ }^{21}$ Durumu çözmeye çalışan araştırmacılar, aslında bu şakaların çok yaygın bir biçimde yapıldığını öğrenmişlerdir. Bu durum, "sağlıklı arkadaşlık kurulamaması” konusunda mutlaka altı çizilmesi gereken bir sorun olarak görülmüştür.

Türk arkadaşları olmayan (özellikle Türkçe bilmeyen) "göçmen öğrencilerin bir arada olmaları, teneffüslerde ve okul sonrasında birlikte oynamaları” da Türk öğrencilerin bazıları için bir sorun olarak görülmüştür. "Gruplaşıp kavga ediyorlar” söylemini doğuran bu durum önyargılarla da beslenerek, özellikle liseli erkek öğrencilerin birbirleri ile yaşadıkları bazı olayların kavgalara dönüşmesine neden olmaktadır. Bu çerçevede yaşanan ve temelde aynı dili konuşamamakla ilişkili olan durum, zaten Türk ve göçmen öğrenciler arasında zaman zaman ortaya çıkan soğukluğu daha da arttırmaktadır. ${ }^{22}$

Göçmen öğrencilerin iyi sınıflarda (seçme sınıf, üniversite/lise sınavlarında başarılı olacağı varsayılan sınıf gibi düşünülen sınıflarda) olmadıkları ve sınıflar arasında eşit bir biçimde dağıtılmadıkları gözlenmiştir. Bu durum da doğrudan eğitim dilini iyi bilmemekle ilişkilidir. Türkçeyi bilmemek ayrıca dersleri anlayamamak hatta yeterince zeki olmamak algısını da doğurmaktadır. Dil bilmeyen kişi ayrıca akranları tarafından adeta görünmez olmaktadır.

Arapça dersleri olmasına rağmen, Türk öğrencilerin Arap arkadaşlarından Arapça öğrenebileceklerini neredeyse hiç düşünmemeleri de ilginç bir durumdur. Arap öğrenciler arasında az da olsa Türk öğrencilere soru soranların olduğu görülmüş ancak bunun da istisnai bir durum olduğu anlaşılmıştır. Proje anlatıldığında, öğrencilerin birbirlerine yardım edebileceklerini düşünmeye başladıkları hatta konuya çok sıcak baktıkları görülmüştür. Bu anlamda öğrenci katılımındaki “gönüllülük oranının” çok yüksek olduğu söylenebilir.

21 Öyle anlaşılıyor ki "küfür etmek" üzerinden yaşanan bu durum sadece Çorum'da yaşanmamakta Türkiye'nin başka yerlerinde de örnekleri bulunmaktadır. Din kültürü öğretmenleri ile yapılan çalışmada bir öğretmen de benzer konuya değinmiştir. Öğretmen; meseleyi “...çocuklar şikâyet ederken Suriyeliler bize küfretti diyor, ne dedi diyorum, bilmiyorum ama küfretti sanırım diyor, yani tamamen önyargıdan kaynaklanan bir problem" biçiminde dillendirmiştir. (Altuntaş, 2018, s. 482). İstanbul Ataşehir'de öğretmenlerle yapılan görüşmeye dayanan bir araştırmada da ilk dönemde yaşanan önyargıların, öğretmen ve idarecilerin çabaları ile ortadan kalktığı hatta "akran kabulüne" evirildiği dile getirilmiştir (Karaağaç ve Güvenç, 2019, s. 552).

22 Din kültürü ve ahlak bilgisi dersi öğretmenleri ile yapılan bir alan araştırmasında da öğretmenler, Suriyeli öğrencilerin Türkçe bilmemesiyle kendi aralarında gruplaşmaları arasında ilişki olduğunu düşünmektedirler (bkz. Altıntaş, 2008, s. 473 vd.). 


\section{2- Öğretmenlerin yanlış tutumu ve nasıl davranacaklarını bileme-} meleri: Mevcut öğrencilere ayrıca göçmen öğrencilerin eklenmesi şüphesiz öğretmenler için iş yükünü arttıran bir durumdur. Üstelik göçmen öğrenciler için dil de önemli bir engel olarak ortaya çıkmaktadır. İş yükünü artırma potansiyeli taşıyan yeni öğrencilere karşı önyargılar, politik tercihlerin beslediği olumsuzluklar ve bu özel öğrenci grubuyla nasıl ilgileneceğini bilememe öğretmenler açısından sorunu anlatan üç önemli noktadır. Bu üç önemli unsurun birleşmesi şüphesiz ciddi bir sorun olarak okunabilir.

Dil bilmeyen göçmen öğrencilerle iletişim kuramayan bazı öğretmenlerin $^{23}$ tipik tavrı, öyle anlaşılıyor ki onları yok saymak olmuştur. Zira Türkçe bilmeyen birçok öğrenci, sınıfların en arka sıralarında oturmakta ve hiçbir etkileşim olmadan günü bitirmektedirler. Gerçekten de özel bir ilgi gerektiren, göçmenlere yönelik eğitim hakkında hiç bilgisi olmayan öğretmenlerin bu tavrı hem öğretmenlerin beyanlarından hem de öğrencilerin beyanlarından anlaşılmaktadır. Bu tavrın arkasında bazı öğretmenlerde bulunan "politik bir tepkisellik” olduğu da görülmüştür. Göçmenlere yönelik toplumda yer alan yaygın önyargıların bazı öğretmenler tarafından da aynı şekilde dillendirildiği tespit edilmiştir. ${ }^{24}$

Birçok öğretmen, kendi sınıflarında bulunan göçmen öğrencilerden sıklıkla "Suriyeli öğrenciler” diye bahsetmiştir. Ancak sözünü ettikleri öğrencilerin aslında Iraklı olduklarını bilmedikleri anlaşılmaktadır. Bu da birçok öğretmenin öğrencilerle sağlıklı bir diyalog geliştiremediğini, onlarla ilgilenme gereği dahi duymadığını göstermektedir.

Ortaokul düzeyinde bazı sinıflarda genel tablonun aksine göçmen öğrenciler ile Türk öğrencilerin karışık bir biçimde oturdukları ve arkadaşlık ilişkilerinin nispeten iyi olduğu gözlenmiştir. Bu tablonun oluşmasında özellikle sorumlu sınıf öğretmenlerinin duyarlı davranmaları ve göçmen öğrencileri kabullenmelerinin oldukça etkili olduğu anlaşılmıştır.

23 Dil bilmeyen öğrencilerle yaşanan sorunlar (ayrıca göçmen öğrencilerin yaşadığı sorunlar) konusunda öğretmenlerin düşüncelerini ve gözlemlerini yansıtan bir çalışma için bkz. (Altıntaş, 2018).

24 Öğretmenlerin göçmen öğrencilere karşı nasıl davranacaklarını bilememesi, bu alanın aslında özel bir eğitim gerektirdiğini göstermektedir. Aynı durum göçmenlere alışık birçok Batı ülkesi için de geçerlidir. Örneğin Kanada'daki öğretmenler, özellikle travma yaşayan ve psikolojik desteğe ihtiyaç duyan öğrencilere karşı nasıl çaresiz kaldıklarını dile getirmektedirler (bkz. Gagné vd., 2018, s. 60 vd.). Aynı çalışmada, araştırmacılar tarafından göçmen öğrencilerin sorunları ile ilgilenmede ve çözmede başarılı bulunan okullarda bile bazı öğretmenlerin göçmen öğrencilere karşı ciddi önyargılar taşıdıkları ve sorunları çözmede isteksiz davrandıkları da tespit edilmiştir. Gagné vd., 2018, s. 66).

Öğretmenlerin göçmen öğrencilerine karşı önyargılarını da anlatan bir çalışma için ayrıca bkz. (Altuntaş, 2018, s. 482 vd.). Aynı çalışmada öğretmenlerin sorunlarla baş edecek yeterliliklerinin ve araçlarının olmadığına da değinilmiştir (s. 489 vd.). 
Kendi sınıfı, diğer sınıflardan farklı olan bir öğretmen; bunu "her göçmen öğrenci için bir body seçerek hallettiğini” anlatmıştır. Oluşturduğu sistemde öğretmen, her göçmen öğrenci için bir gönüllü Türk öğrenci belirlemiş, hem göçmen öğrenci ile arkadaşlık kurmasını hem de ona derslerinde yardımcl olmasını istemiştir. Böylece kendisini sınıfa ait hisseden göçmenler hem derslerinde başarılı olmuşlar hem de Türkçeyi çok daha iyi öğrenmişlerdir. Sonuçta tek bir öğretmenin çabası ile o sınıfa giren tüm öğretmenlerin de işi kolaylaşmıştır.

Öğretmenlerin nasıl davranacaklarını bilememesini, bazı eğitimler vererek ve iyi uygulama örneklerini göstererek çözmek mümkündür. Önyargıları $\operatorname{aşmak}^{25}$ ve politik tutumları değiştirmek çok daha zor olsa da bunların etkisini sınırlamak çok da zor görünmemektedir. Yukarıda örnekleri verilen ve çok kısa süre içinde haberdar olunan az sayıdaki öğretmenin küçük gayretleri, sorunları çözme hususunda umut vermektedir. Bu somut, denenmiş ve başarılı olmuş gayretlerin önemli olduğu ve belki de sorunları çözmede anahtar olabileceği vurgulanmalıdır.

3- Yöneticilerin ne yapacağını bilememesi: Öğrenci sayısı oldukça kalabalık olan okullarda bir de göçmen öğrencilerin olması yöneticilerin işini zorlaştırmaktadır. Bazı öğretmenlerin tepkileri, Türk öğrenci velilerinin göçmenlere yönelik önyargıları, Türk ve göçmen öğrencilerin kendi aralarında anlaşamamaları (bazen kavga etmeleri) işi zorlaştıran sebepler arasında sayılabilir. Özellikle öğrencilerin kendi aralarında yaşadığı sorunların sonucu, ister istemez sıkı disiplin önlemleri almak, sorun çıkaranları dışlamak hatta okuldan uzaklaştırmak biçiminde kendini göstermektedir. ${ }^{26}$

Göçmen öğrencilerin çok büyük oranda okula devam etmedikleri gözlenmiştir. Ancak devam etmeme nedenleri konusunda okul yöneticilerinin genel tahminler dışında fikirleri olmadığı da görülmüştür. Şüphesiz yöneticilerin elinde öğrencilerin neden okula devam etmediğini araştıracak personelin ve maddi imkânların olmadığı söylenebilir. Ancak göçmen öğrencilerin sorunları arttırdığı konusunda genel bir yargının baskın olduğu düşünüldüğünde,

25 Önyargıları aşmanın en önemli göstergelerinden biri göçmen öğrencilerin sınıf için olumlu katkılar sunduğunun kabul edilmesidir. Sürekli olumsuzluklarla anılmaları mevcut durumu iyileştirmek yerine daha da kötüye götürecektir. Bu çalışmada "sınıfa katkı" konusunda "dil” bir fırsat olarak düşünülmüştür.

Kanada'da öğretmenler ile yapılan bir alan araştırmasında öğretmenlerin \%73'ü Suriyeli öğrencilerin kendi sınıflarına "değerli katkılar" sunduklarını belirtmişlerdir (Gagné vd., 2018, s. 65). Bu olumlu izlenim sorunları tespit etmek, kendileri başta olmak üzere muhatapların eksikliklerini görmek ve sonuçta çözüm önerileri geliştirmek açısından çok anlamlı bir tespit olarak görülmektedir.

26 Göçmen öğrencilerin şiddet ve anlaşmazlık durumunda; akranları, öğretmenleri ve idareciler nazarında nasıl değerlendirildiklerini yansıtan ve göçmen öğrencilere karşı uygulanan fiziksel ve psikolojik şiddete de değinen bir çalışma için bkz. (Altuntaş, 2018, s. 483 vd.). 
“daha az göçmen öğrencinin daha az sorun olduğu” biçiminde bir düşüncenin de mevcut olduğunun altı çizilmelidir.

Göçmenlerin özellikle savaş ortamından geldikleri, bazılarının travmatik olaylar yaşadığı, ailesinden fertler kaybettiği düşünüldüğünde psikolojik desteğin önemli olduğu görülür. Ancak okul yöneticilerinin bu durumu önceleyecek bir farkındalığa sahip olmadığı, bu farkındalık olsa da bu konuyu birlikte değerlendirebilecekleri personellerinin olmadığı görülmektedir. Özelikle savaştan etkilenen göçmen öğrenciler konusunda uzman; yöneticileri ve öğretmenleri yönlendirecek; diğer öğrencileri ve hatta velileri bilgilendirecek uzmanlara veya rehberlik ve danışmanlık öğretmenlerine ihtiyaç olduğu anlaşılmaktadır. Dil engelini aşmak için bu uzmanların ve/veya öğretmenlerin bir kısmının göçmenlerin dillerini bilmeleri veya göçmenler arasından istihdam edilmeleri de oldukça yararlı olabilir.

\section{4- Göçmen öğrencilerin maddi zorluklarının ve kültürel farklılıkların} sorun olması: Birçok göçmen öğrenci maddi sıkıntılar yüzünden ya okula devam edememekte ya da okul sonrasında çalışmak zorunda olduğundan dersleri ile ilgilenememektedir. Okula bir şekilde devam eden öğrenciler arasında da devamsızlığın çok fazla olduğu görülmektedir. Okula gelmeyen öğrencilerin neden gelmediğine dair somut bir veri olmamakla birlikte, devamsızlığı fazla olan ve arada okula gelen birçok öğrencinin "maddi sorunlar" ve “çalışma zorunluluğu” gibi gerekçeler sunması bu tespiti anlamlı kılmaktadır. Ayrıca birçok işyerinde okul çağında olan göçmen çocukların çalışıyor olduğunu görmek de bu tespiti destekler.

Maddi zorluklar ve okula devamsızlık; ister istemez okula adapte olamama, Türkçeyi yeterince öğrenememe ve okulda iyi arkadaşlıklar kuramama gibi sonuçlar da doğurmaktadır. Bu da sosyalleşme dolayısıyla entegrasyon işlevini sağlayacak bir mekan olarak okulun başarısını olumsuz etkilemektedir. Kültürel farklar ve önyargılar ile birlikte bu olumsuzluğun arttığı söylenebilir.

Hem Türk öğrenciler hem de göçmen öğrenciler somut bir şekilde dile getirmeseler de "biz ve onlar" dilini kültürel farklılıklarla ilişkilendirerek kullanabilmektedirler. Göçmenlere yönelik önyargılar ve göçmenlerin buna verdikleri tepkiler ister istemez bir mesafe oluşturmakta ve arkadaşlık ilişkilerinin yeterince gelişmemesine neden olmaktadır. Bu genel tespite karşın göçmen öğrencilerin nerede ise tamamı Türkiye'de olmaktan mutlu olduklarını, küçük sorunları aşabileceklerini ve Türk arkadaşları ile daha iyi ilişkiler kurabileceklerini ifade etmişlerdir. Aynı şekilde Türk öğrencilerin de önemli bir kısmı arkadaşlıklar konusunda mevcut durumu iç açıcı bulmasalar da ciddi bir sorunun da olmadığını dile getirmişlerdir. 
Kendilerinin dışlandığını düşünen bazı göçmen öğrencilerin, Türk öğrencilerle arkadaşlık konusunda istekli olmadıkları gözlenmiştir. Bazı öğrencilerde ciddi bir umutsuzluk ve geri dönme isteğini de besleyen dişlanmışlık duygusu, dil öğrenme konusunda da olumsuz bir sonuç doğurmuştur. Kendisini bu şekilde hisseden öğrencilerin Türkiye'ye geliş tarihleri her ne kadar geriye gitse de Türkçe öğrenemedikleri/daha az öğrendikleri görülmüştür.

\section{Uygulama Sonrası Tespitler}

Dil etkinliği başlarken, devam ederken ve sonuçlandıktan sonra proje araştırmacılarının gözlemleri ve öğrencilerin onlara anlattıkları, idarecilerin ve öğretmenlerin geribildirimleri sonuçların elde edilmesinde ciddi bir rol oynamıştır. Bir önceki başlıkta, etkinlik aşamasına geçmeden önce tüm tarafla yapılan görüşmeler ve okul ortamının gözlemlenmesiyle elde edilen veriler değerlendirilmiştir. Bu başlıkta ise etkinlikler bittikten sonra dil öğrenme/ öğretme işinin bir araç olarak etkileşimde ne kadar anlamlı olduğuna dair tespitler üzerinde durulacaktır.

Çalışmalar sonucunda elde edilen genel tespit; etkinliklerin başlamasıyla artan bir araya gelmelerle birlikte önyargıların da azaldığı ve etkileşimin arttığı şeklinde olmuştur. Bu açıdan projenin amacını ulaştığı söylenebilir. Ancak elde edilen sonuçlara daha yakından bakıldığında önyargıların azalması ve etkileşimin artmasının farklı yansımaları olduğu da görülecektir.

1. Bu çalışma tüm taraflar için yararlı olmuştur: Çalışmaları liselerde doğrudan proje araştırmacıları yönettikleri için daha kontrollü bir biçimde yürütülebilmiştir. Ortaokullar ise bazı öğretmenlerin isteksiz davranmalarından dolayı istenen düzenlilikte yürütülememiştir. Ancak bir şekilde projeye dâhil olan öğrencilerin her fırsatta, projenin kendileri için çok yararlı olduğunu söylemeleri, hem ortaokul düzeyinde hem de lise düzeyinde bu tarz çalışmalara ciddi ihtiyaç olduğunu anlatmaktadır. Ayrıca projeye destek sunan yöneticilerin ve öğretmenlerin de projenin öğrencilerin yanı sıra kendileri için de yararlı olduğunu ifade etmeleri oldukça anlamlıdır. Göçmen öğrencilerin derslere ilgilerinin artması, Türk öğrencilerin ise özellikle Arapçayı daha çok önemsemeleri bu açıdan göze çarpan çıktılardır.

2. Çalışmalara katılan öğrencilerin dil düzeyleri artmıştır: Etkinlikler sonucunda öğrencilerin hemen hepsi dil öğrenme konusunda ciddi mesafeler almıştır. ${ }^{27}$ Etkinliğe başlarken tercüman aracılığı ile görüştüğümüz onlarca

27 Proje sonucunda hem Türk hem de göçmen öğrencilere, "dil yarışmasına” kimlerin katılacağını belirlemek için bir sınav yapılmıştır. Bu sınavlarda başarı oranı, Türk öğrenciler açısından Arapça derslerinden alınan notlar düşünüldüğünde; göçmen öğrenciler açısından ise tüm derslerin ortalamaları düşünüldüğünde nispeten yüksek olmuştur. Ancak amaç, dil öğrenmeyi etkileşim ve uyum için bir araç kılmak olduğundan, araştırma yöntemine de uygun olan "ölçmek yerine anlamak" öncelenmiş ve bu sınavın sonuçları ayrıntılı bir biçimde ayrıca analiz edilmemiştir. 
öğrenci ile etkinlik bitiminde tercümansız anlaşabiliyor olmak en azından göçmen öğrenciler açısından “dil öğrenme amacının” önemli bir ilerleme ile sonuçlandığını göstermektedir. Türk öğrencilerin de dillerini ilerlettiklerini beyan etmeleri her iki tarafın bu işten kazançlı çıkabileceğini göstermiş ve projenin bu amacına da ulaştığını ortaya koymuştur.

3. Çalışma ile beraber Türk öğrenciler ile göçmen öğrencilerin arkadaşlıkları artmıştır: Çalışma sonucunda sınıflarda yan yana oturmaların fazlalaşması, teneffüslerde dil öğrenmeden bağımsız bir biçimde birlikte oynamaların görülmesi, proje çıktıları içinde en sevindirici olanı olmuştur. Konuyu çarpıcı bir biçimde ortaya koyan bir olay şu şekilde yaşanmıştır: Kız lisesinde hangi öğrencilerin kimlerle grup olacağı konuşulduğunda, göçmen bir öğrenci istemediği bir gruba düştüğü için ağlamaya başlamıştır. Gruptan sorumlu olan araştırmacıya o öğrenci, "grupta sevmediğim kişiler var ben etkinliğe katılmak istemiyorum” biçimimde bir açıklama yapmıştır. Öğrenciye grubun dil öğrenmek için bir araç olduğu, bu konuyu çok sorun etmemesi gerektiği, isterse ayrılabileceği ya da başka bir gruba geçebileceği ancak kendisi için en uygun grubun bu grup olduğu ve kendisine bu grubun tavsiye edildiği anlatılmış ve öğrenci ikna olmuştur. İki hafta sonra bu öğrenci, gruptan sorumlu araştırmacıya kendisini bu grupta bıraktıkları için teşekkür etmeye gelmiştir. Nedeni sorulduğunda ise çok iyi dostluklar kurduğunu anlatmıştır.

4. Karşılıklı önyargılar azalmıştır: Göçmen ve Türk öğrencilerin önyarg1larını önemli oranda kırdıkları hem kendi ifadelerinden hem de gözlemlerden ortaya çıkmıştır. Dil etkinliği esnasında, genel anlamda öğrencilerin birbirlerini daha yakından tanımaya başladıkları ve iyi arkadaşlık ilişkileri kurdukları söylenebilir. Araştırmacıların okul ziyaretlerinde; (1) okul bahçesinde oynanan oyunlarda Türk öğrencilerle göçmen öğrencilerin daha çok bir arada oynamaya başladıkları ve (2) sınıflarda yan yana oturmaların çoğaldığı gözlenmiştir. Ayrıca görüşmelerde; (3) dersler konusunda bazı Türk öğrencilerle göçmen öğrencilerin birbirlerine yardım etmeye başladıklarını söylemeleri ve belki de en önemlisi (4) oyunlarda olmayan grup arkadaşlarının nerede olduğundan haberdar olmaları karşılıklı önyargıların kalkmaya başladığına dair göstergeler olarak sunulabilir. Ancak kız öğrenciler ile erkek öğrenciler, göçmen öğrenciler ile Türk öğrenciler, lise öğrencileri ile ortaokul öğrencileri arasında ciddi farklar olduğu da anlaşılmıştır. Birincilerin ikincilere göre daha fazla gelişim gösterdikleri görülmüştür.

Yaşın küçüklüğü ile etkileşimin yoğunluğu arasında kurulabilecek bir ilişki düşünüldüğünde, liselilerin ortaokullulara göre daha fazla gelişim göstermeleri yadırganabilir. Bu durum proje uygulamasının lise ve ortaokul düzey- 
lerinde farklı olması ile ilişkilidir. İlk fark, ortaokullarda etkinliklerin liselere göre iki hafta daha kısa sürmesidir. İkinci fark ise liselerde araştırma ekibinin grupları belli düzenlilikte ziyaret etmesi ve bu ziyaretlerin grup bağlarını sıkı tutmasını sağlamasıdır. Öte yandan, ortaokullarda bazı öğretmenlerin grupları takip etmemesi sonucunda grup bağlarının gelişmediği buna bağlı olarak öğrenci ilgisinin ve gelişiminin zayıfladığı saptanmıştır.

\section{Sonuç ve Değerlendirme}

Projemize benzer çalışmalardan da söz edilebilir. Sakarya Gençlik Merkezi tarafından 2013 yılında yürütülen “Dil Kardeşliği Projesi” bu anlamda ilginç bir çalışmadır. İsim benzerliği ile dikkatimizi çeken bu çalışma hakkında, maalesef Gençlik ve Spor Bakanlığının internet sayfasında ve bazı haber sitelerinde yer alan ve projenin başladığına dair kısa haber dışında herhangi bir bilgiye ulaşılamamıştır. Bu haberde projenin mahiyeti ve ne tür bir proje olduğu söylenmemekte ancak yabancı öğrencilerle Türk öğrencilerin Gençlik Merkezi’nde buluşturulmak istendiği anlatılmaktadır. Böylece öğrenciler birbirlerine anadillerini ve kültürlerini öğreteceklerdir (haberler.com, 2013; GSB, 2013). Akademik bir çalışma olarak planlanmadığı anlaşılan bu projede (öğrencilerde nasıl bir ilerleme olduğuna dair bir tespit yapılmaması), öğrencilerin doğal ortamlarında değil de haftanın belli günlerinde Gençlik Merkezi'ne gitmeleri (dolayısıyla ek bir zaman harcamaları), etkinliğin ortaöğretim değil de üniversite düzeyinde yapılması, etkinliğin göçmenlere karşı önyargının belirginleşmemiş olduğu bir dönemde yapılması (2013 yılında) ve etkinliğin doğrudan entegrasyon düşünülerek yapılmaması gibi bazı özellikleri olmakla beraber bu tarz çalışmaların yenilenmesi ve denenmesine ciddi ihtiyaç duyulduğu belirtilmelidir.

"Dil Arkadaşlığı” adını taşıyan ve iki ortaokul öğrencisi tarafından tasarlanan, takdire şayan bir çalışma göçmen öğrencilerin "okul kültürüne uyum süreçlerini hızlandırmak" amacıyla yapılmış ve "birbirlerine dillerini öğretmeyi” temel almıştır. Ayrıca bu projede akademik konularda birbirlerine destek olacak bir akran yardımlaşma sistemi oluşturulmaya çalışılmıştır. “TÜBİTAK 12. Ortaokul Öğrencileri Araştırma Projeleri Yarışması”nda dereceye giren projenin özellikle "Değerler Eğitimi” alanında başarılı olması da oldukça manidardır (Bektaş ve Şam, 2018, s. 44). “TÜBİTAK 13. Ortaokul Öğrencileri Araştırma Projeleri Yarışması"nın Ankara bölgesinde dereceye giren ve "akran desteğinin” altını çizen bir çalışma daha göze çarpmaktadır. Çalışma sonunda 8 Türk ve 8 Suriyeli ortaokul öğrencisi ile yapılan uygulamada olumlu sonuçlar alındığı ifade edilmiştir. Bu çalışmada öğrencilerin; akademik alanda 
dayanışmalarının yanı sıra kültürel farkındalık konusunda da önemli bir yol aldıkları görülmüştür (Aslan H., 2020). Aynı şekilde, bizim de şahit olduğumuz bir öğretmenin "her göçmen öğrenciye bir body" ayarlayarak yaptığı uygulama da buna dâhil edilebilir.

Okullarda yapılan benzer faaliyetlerde özellikle öğrencileri merkeze alan, öğretmenler tarafından desteklenen "gönüllü” çalışmaların başarı oranlarının çok yüksek olacağı söylenebilir. Entegrasyon konusunda bu tarz uygulamalara bütçe ayrılması öncelikli politikalar arasında yer almalıdır. Bu çalışmaların hedefi, her ne kadar uygulamada ve yöntemde farklılıklar olsa da Dil Kardeşliği çalışmamızın hedeflerine uymaktadır. Bu tarz çalışmalar göçmen öğrenciler ile Türk öğrenciler arasındaki etkileşimi artıracağından anlamlı görünmektedir.

Bu konuda “dil köyü” biçiminde anılan bir başka düşünceden de söz etmek yararlı olacaktır. "Dil köyü” önerisi (okul dışında olmasından dolayı projemizden farklılaşsa da) ticari olmayan ve karşılıklı faydaya dayanan bir düşüncedir. Ancak bu düşünce sadece öneri olarak kalmış, her ne kadar zaman zaman "proje” olarak anılsa da ayrıntılandırılmamış ve henüz uygulama alanı bulamamıştır. Yapılan internet araştırmasında üç farklı “dil köyü” değinisine rastlanmıştır;

(1) Suriyeli ve Türkiyeli öğrenciler ile akademisyenlerin bir araya gelmesi sonucunda bir dil öğrenme aktivitesinin gerçekleştirilmesi (Tanrıkulu, 2017, s. 26);

(2) Şehre yakın ve her şeyin Arapça olarak düzenlendiği, dolayısıyla yurtdışına gitmenin bir alternatifi olacak şekilde bir köy kurgusu; ${ }^{28}$

(3) İstihdam edilecek kişilerin bulunmadığı yerlerde Suriyelilerin istihdam edilmesi ve bu süreçte isteyene ayrıca bu Suriyeliler tarafından Arapça öğretilmesi öngörülmektedir (Aldemir, 2016, s. 218).

Şüphesiz uygulanamadan bu önerilerin başarı şanslarının ne olacağını bilinemez. Ancak ilk öneride dil öğrenmenin maliyetinin düşeceği, ikincisinde bir dil öğrenme tekniğinin deneneceği ve üçüncüsünde ise bir taraftan üretime katkı olacağı diğer taraftan da İslami kaygılarla Arapçanın öğrenilme gerekliliği vurgulanmaktadır. Ancak maliyetin her ne kadar az olacağı iddia edilse de köy oluşturmak ya da mevcut köyleri bu amaç için seferber etmek yine de ciddi bir uğraş ve maliyet anlamına gelecektir. Tüm bu soru işaretlerine karşın yine de bu tarz düşünceleri hayata geçirmeye çalışmak, ciddi yararlar sağlayacak bir potansiyele sahip gibi görünmektedir. Göçmenlerle birlikte dil öğrenme aktivitelerinin her açıdan ciddi katkıları olacağı kesindir. 
Bu tarz düşünceler sadece okullar ve öğrenciler düşünülerek değil de daha geniş bir perspektifle öğrenci olmayanları da kapsayacak şekilde ele alınırsa “dil köyleri” çok önemli başka açılımlar da sağlayabilir.

Entegrasyonu sağlama potansiyeli olan bu tarz “ötekileştirmeyen”, “insanlar arasındaki eşitliği öne çıkaran” etkinlikleri denemeye ısrarla devam etmek gerekir. Başta Avrupa ülkeleri olmak üzere dünyada istenen başarının sağlanamadığ129, oluşturulan sistemlerin yabancıları dışladığı gibi birçok eleştirinin olduğu hemen akla gelebilir. Ancak ev sahibi ülkenin sadece kendi dilini göçmene öğretmesi değil, göçmenin dilini de kendi yurttaşlarına yabancı dil olarak öğretmesi hem eğitimi kolaylaştıracak hem de göçmenlere karşı önyargıları yıkacak bir unsur olarak görülebilir. Hatta bunu bırakın sorun olarak görmeyi bir fırsat olarak değerlendirecek bir model oluşturmak da hedeflenebilir. Şüphesiz bu başarılabilirse çok değerli bir kazanım olacaktır. Bu proje tam da bu noktaya odaklanarak böyle bir model üzerine düşünmeyi önermektedir.

Yabancı dilin ne olduğu, bu yabancı dile ihtiyaç olup olmadığı tabii ki tartışılabilir. Ancak Türk eğitim sistemi ve küresel ilişkiler, diplomasi, piyasalar düşünüldüğünde İngilizce, Rusça, Arapça, Çince, İspanyolca gibi bazı dillerin öne çıktığı söylenebilir. Çorum’a baktığımızda yabancı ülkelerle yapılan ticaret potansiyelinin önemli olduğu, özellikle Ortadoğu, Orta Asya ve Afrika ülkeleri ile bu potansiyelin gün yüzüne çıkabileceği düşünülebilir. Çorum’a gelen göçmenlerin niteliği açısından da bu potansiyelin kesişen kümesi olarak Arapça, Farsça, Afrika'da konuşulan bazı diller ve Urduca görülebilir. Gerçekten de Arapça (Çorum'daki göçmenlerin en çok kullandığı ana dil), Farsça (Çorum'daki göçmenlerin en çok kullandığı ikinci anadil) ve diğer bazı diller (özelikle sayıları nispeten az olsa da Afrika ülkelerinde konuşulan diller ve Urduca) ihtiyaç olarak sunulabilir. Bu proje, göçün firsatlarından biri olarak sözü edilen durum düşünüldüğünde, “dil kardeşliği”ni önemsemektedir.

“Dil Kardeşliği: Göçmen Öğrencilerle Etkileşimde Dilin Rolü Olabilir mi?” çerçevesinde uygulanma imkânı bulan projenin sağladığı veriler, "fırsatlar" olarak okunabilir:

(1) Bu çalışma ile insanların birbirlerini tanıdıkça önyargılarının azalıp azalmayacağı ve uyum sürecinin artıp artmayacağı sorusuna cevap aranmış ve

29 Göçmen öğrencilerin entegrasyonu konusunda gelişmiş Batı ülkelerinin çok da dillendirilmeyen bir avantajı olduğu söylenebilir. Bu da uzun zamandan beri göçmenlere alışık olmaları ve çok farklı nesillerden göçmenleri barındırmalarıdır. Örneğin okula giden bir göçmen çocuk, kendisi ile aynı dili konuşan (bir nesil ya da birkaç nesil öncesinden gelmiş ve o ülkeye yerleşmiş) arkadaşlar bulabilmekte üstelik bu arkadaş o ülkenin de dilini çok iyi bilmektedir. Kanada örneğinde aynı dili konuşan akranlar ile ilgili bir değerlendirme için bkz. (Gagné vd., 2018, s. 61 vd.). Her ne kadar sorunları ve özellikle önyargıları ve ırkçılığı sıfırlamasa da okul yöneticileri, öğretmenler, veliler ve akranların da göçmen öğrencilere alışkın olmaları bir avantaj olarak görülebilir. 
bu cevabın olumlu olduğu, projenin başarıya ulaştığı gözlemlenmiştir.

(2) Bu başarı; erkeklere oranla kızlarda, ortaokullara oranla liselerde, Türk öğrencilere oranla göçmen öğrencilerde daha belirgin olmuştur.

(3) Göçün olumlu sonuçlarının olabileceği “bir dil etkinliği” ile ortaya konmuştur.

(4) Kültürel karşılaşmanın, göçmenlerin özellikleri bilinerek (bizim örneğimizde dil bilmek ve dil öğrenmek istemek) daha avantajlı hale getirilebileceği anlaşılmıştır.

(5) Uyumu kolaylaştıran ve oldukça yararlı olan bu potansiyeli açığa çıkarmak için, (uygulanan yöntemin kullanılmasıyla) hiçbir maddi harcamaya gerek duyulmayacaktır. Çünkü öğrencilerin kendi doğal ortamlarında, sohbet ederken veya oyun oynarken dil öğrenmeleri öngörülmektedir.

(6) Herhangi bir günü ya da tatili bu iş için ayırmak gerekmediğinden ek bir zaman da harcamaya gerek yoktur.

(7) Dil kardeşliği; tanımayı ve kaynaşmayı merkeze aldığı için göçmenler açısından uyum sürecini (örneğin okul derslerine olan ilginin artması) ev sahibi ülke yurttaşları açısından da kabul sürecini (örneğin önyargıların azalmasını) hızlandıracak bir uygulama olmuştur.

(8) Bu çalışma ile (yabancı dil öğrenimi ve göçmenlere Türkçe öğretimi konusunda sorunların yaşandığı sürekli dile getirilen eğitim sistemimiz için) bir model de denenmiştir. Kendi anadillerini eğlenceli bir biçimde karşısındakine öğreten ve onun anadilini de öğrenen akranların, başarılı olup olmayacakları sınanmış ve bu modelin başarılı olduğu anlaşılmış ve geliştirilebileceği sonucuna varılmıştır.

(9) Uyum politikaları için ulusal ve yerel düzeyde politika yapıcılara özellikle eğitim ve dil alanında yapabileceklerine dair öneriler ortaya çıkmıştır.

(10) Proje yerel düzeyde; Üniversite, STK, İl Milli Eğitim Müdürlüğü ve İl Göç Müdürlüğü arasında bir işbirliği örneği olmuş, göçmenlik gibi çok önemli ve tartışmalı bir konuda gelecekte daha iyi çalışmaların yapılması için bir altyapi oluşturulmuştur.

(11) Projede çok sayıda genç araştırmacı görev almış, onların akademik gelişmesine yardımcı olunmuştur.

(12) Projeye dair haberler kamuoyu ile paylaşılarak bir farkındalık oluşturulmuştur. 
Dil Kardeşliği projemizin, her ne kadar proje kapsamında "dil öğrenmek / öğretmek” etkileşim için bir araç olarak görülse de dil öğrenme/öğretme modeli açısından zayıf tarafı uzman öğreticilerin olmamasıdır. Bu durum ciddi bir eksiklik olarak düşünülebilir. Gerçekten de dil öğretimi uzmanlık gerektirmektedir. Ancak doğal ortamında dil öğrenmek kadar etkili ve kalıcı bir metodun olmadığını da göz ardı etmemek lazım. Bu doğal ortamın, ana dili öğrenilmek istenen grubun arasında olmakla ilişkili olduğu düşünüldüğünde her iki grubun da birbirlerine kendi anadillerini öğretmeye çalışmaları "doğallığa” en uygun tekniklerden biri olacaktır. Üstelik öğretmenlerin işin içine girmesi (ki kullanılan teknikte ikincil bir öğe olacaktır) uzman ihtiyacını kısmen karşılayacak bir unsur olarak da not edilebilir.

Sonuçta proje kendi sınırlı çerçevesi içinde tüm sorunları çözme iddiasında değildir. Ama göçün olumlu sonuçlarının olduğu, entegrasyon sürecinin insanların birbirlerini daha iyi tanımalarıyla daha sorunsuz olacağı, göçmenlerle ilgili politikaların özellikle uyum sürecine yoğunlaşmasının gerektiği, kültürel karşılaşmaların göçmenlerin özellikleri bilinerek avantaja çevrilebileceği ve bu durumun kamuoyu ile paylaşılmasının önemli olacağı sonucuna ulaşılmıştır.

\section{Kaynakça}

Adıgüzel, Yusuf (2019), Göç Sosyolojisi, Ankara: Nobel Yayınları.

Akın, H. Bahadır, Yılmaz Seçim ve Şeyma Akın (2020), "Syrian Refugees and Peaceful Coexistence: Dining Spaces as Contact Points", Liberal Düşünce Dergisi, s. 99, ss. 125-144.

Aldemir, Turgut (2016), "Röportaj”, ilahiyat Akademi Dergisi, Röportajı Yapan: Tuba Erkut, s. 4, ss. 207-222.

Altıntaş, Muhammed Esat (2018), “DKAB Öğretmenlerine Göre Suriyeli Çocukların Devlet Okullarında Karşılaştıkları Sorunlar (Nitel Bir Araştırma)". Marife Dini Araştırmalar Dergisi, s. 2, ss. 469-499 .

Aslan, Ahmet (2020), "Suriyeli Öğrencilerin İkincil Sosyalleşmeleri Bağlamında Okulun İşlevleri: Çarşamba İlçesi Örneği”, Anadolu Eğitim Liderliği ve Öğretim Dergisi, s. 1, ss. 42-58.

Aslan, Hayrunnisa (2020), "Suriyeli Öğrencilerin Akran Desteğiyle Okula Uyum Süreci: Bir Eylem Araştırması”, Uluslararası Sosyal Araştırmalar Dergisi, s. 71, ss. 660-667.

Atasü Topçuoğlu, Reyhan (2014), "Hayatı Değiştirmek icçin Yola Çıkanlar - Yola Çıkınca Değişen Hayatlar: Bir Müracaatçı Grubu Olarak Göçmen Çocuklar”, Toplum ve Sosyal Hizmet, s. 1, ss. 89-108.

Bartram, David; Maritsa V. Poros ve Pierre Monforte (2017), Göç Meselesinde Temel Kavramlar, (çev. Itır Ağabeyoğlu Tuncay), Ankara: Hece Yayınları.

Bektaş, Zeynep Birgül ve Rabia Şam, (2018), “ístanbul'da Öğrenim Gören Suriyeli Misafir Öğrencilerin Okul Kültürüne Etkisinin Araştırıldığı Bir Durum Çalışması Olarak: Dil Arkadaşıı̆ı", TÜBiTAK 12. Ortaokul Öğrencileri Araştırma Projeleri Final Yarışması, 7-11 Mayıs 2018, http://kariyerkoleji.com.tr/upload/files/tubitak_ortaokul_ogrencileri_12_ yarisma_30_04_baski-min.pdf (E.T:23 Ocak 2021). 
Canatan, Kadir (2020), Toplumsal Değişim Perspektifinden Göç Sosyolojisi, Ankara: Eski-Yeni Yayınları.

Canavati, Sara E., Cesia E. Quintero, Britt Haller, Dysoley Lek, Sovann Yok, Jack S. Richards ve Maxine Anne Whittaker (2017), “Maximizing Research Study Efectiveness in Malaria Elimination Settings: a Mixed Methods Study to Capture the Experiences of Feld-Based Staf", Malaria Journal, s.362, ss.1-11.

Çetin, İhsan (2012), “Kentsel Ayrışma ve Mekânsal Kümelenme Biçimleri”, IDEALKENT, s. 7, ss. 160-186.

Çorum Post (2019), “Çorum`da 15 Bin 166 Yabancı Yaşıyor”, 1 Ağustos 2019, https://www.corumpost.com/haber/corumda-15-bin-166-yabanci-yasiyor-75672.html (E.T:18 Ocak 2021).

Doğan, Mustafa (2019), Temel Eğitim Kurumlarındaki Afgan Uyruklu Öğrencilerin Sosyal Entegrasyonunda Okulun Yeri: Karaman Örneği, Yayınlanmamış Yüksek Lisans Tezi, Karaman: Karamanoğlu Mehmetbey Üniversitesi Sosyal Bilimleri Enstitüsü.

d'Oultremont, Clémentine ve Anna Martin (2015), “The Migration Crisis: A Stress Test for European Values”, European Policy Brief, s. 38, ss. 1-13.

Emerson, Robert M, Rachel I. Fretz ve Linda L. Shaw (2008), Bütün Yönleriyle Alan Araştırması: Etnografik Alan Notları Yazımı, (çev. A. Erkan Koca), Ankara: Birleşik Yayınları.

Erdoğan, Murat (2020), Suriyeliler Barometresi 2019: Suriyelilerle Uyum İçinde Yaşamın Çerçevesi, Ankara: Orion Kitabevi.

Gagné, Antoinette; Nadeen Al-Hashimi; Michelle Little; Morgan Lowen ve Anoop Sidhu (2018), "Educator Perspectives on the Social and Academic Integration of Syrian Refugees in Canada”, Journal of Family Diversity in Education, s. 1, ss. 48-76.

Geçici Koruma Yönetmeliği (2014), Resmi Gazete (S. 29153).

Göç Idaresi Genel Müdürlüğü (2021). “Geçici Koruma”, 6 Ocak 2021, https://www.goc.gov.tr/ gecici-koruma5638 (E.T:18 Ocak 2021).

Göksel, Gülay Uğur (2019), Göçmen Entegrasyonu ve Tanınma Teorisi, (çev. Müge Kızıltuğ), İstanbul: Pinhan Yayıncılık.

Gray, David E. (2004), Doing Research in the Real World, Londra: SAGE Publications.

GSB (Gençlik ve Spor Bakanlığı) (2013), “Sakaryalı Gençler Hem Öğreniyor Hem de Öğretiyor”, 27 Aralık 2013, https://gsb.gov.tr/HaberDetaylari/1/3753/aaaaaa (E.T:17 Ocak 2020).

Haberler.com (2013), “Dil Kardeşliği Sakarya'da Başladı”, 23 Aralık 2013, https://www.haberler.com/dil-kardesligi-sakarya-da-basladi-5459008-haberi/ (E.T:17 Ocak 2020).

Harari, Yuval Noah (2018), Hayvanlardan Tanrılara: Sapiens, (çev. Ertuğrul Genç), İstanbul: Kolektif Yayınları.

Harvard, Phillip S. (2016), “A Cultural Context, Curiosity, and Creativity of Innovators: Marie Curie, Nikola Tesla, and Steve Jobs", Igor N. Dubina ve Elias G. Carayannis (ed.), Creativity, Innovation, and Entrepreneurship Across Cultures. Innovation, Technology, and Knowledge Management, New York: Springer, ss. 135-145.

Jamshed, Shazia (2014), “Qualitative Research Method-Interviewing and Observation", Journal of Basic and Clinical Pharmacy, s.4, ss. 87-8.

Kaplan, Mehmet ve Aykut Bedük (2019), “Diaspora Girişimcilik: Suriyeli Girişimcilerin Diaspora Girişim Sahipliği Modeline Bağlı Değerlendirmesi”, Sosyal Ekonomik Araştırmalar Dergisi, s. 38, ss. 231-241. 
Karaağaç, Fatma Cırıt ve Hülya Güvenç (2019), “Resmi Illkokullara Devam Eden Suriyeli Mülteci Öğrencilerin Eğitim Sorunları”, Uluslararası Toplum Araştırmaları Dergisi, s. 18, ss. 530-568.

Karpat, Kemal H. (2003), Osmanlı Nüfusu (1830-1914): Demografik ve Sosyal Özellikleri, (çev. Bahar Tırnakçı), İstanbul: Tarih Vakfı Yurt Yayınları.

Khayati, Khalid (2010), Mağdur Diasporadan Sınır-ötesi Vatandaşlığa, (çev. Fahriye Adsay), İstanbul: Avesta Yayınları.

Kümbetoğlu, Belkız (2015), Sosyolojide ve Antropolojide Niteliksel Yöntem ve Araştırma, İstanbul: Bağlam Yayınları.

Lacroix, Chantal (2010), Immigrants, Literature and National Integration, New York: Palgrave Macmıllan.

Mayring, Philipp (2011), Nitel Sosyal Araştırmaya Giriş, (çev. Adnan Gümüş ve M. Sezai Durgun), Ankara: BilgeSu Yayınları.

McAuliffe, Marie ve Bınod Khadria (2020), "Dünya Göç Raporu”, Uluslararası Göç Örgütü (IOM), https://publications.iom.int, (E.T:18 Ocak 2021).

McConnell, Andrew (2016), "Mülteci ve Göçmen? Sözcük Seçimleri Önemlidir”, UNHCR, https://www.unhcr.org/cy/wp-content/uploads/sites/41/2018/02/UNHCR_Refugee_or_ Migrant_TR.pdf (E.T:19 Ocak 2021).

Moeller, George H., Michael A. Mescher, Thomas A. More ve Elwood L. Shafer (1980), "The Informal Interview as a Technique for Recreation Research", Journal of Leisure Research, s. 2, ss. 174-182.

Nawyn, Stephanie J. (2016), "Constructing "Worthiness" and Resistance to Resettlement of Syrian Refugees", Mobilizing Ideas, 5 Şubat 2016, https://mobilizingideas.wordpress.com/2016/01/05/constructing-worthiness-and-resistance-to-resettlement-of-syrian-refugees/ (E.T:20 Ocak 2021).

ORSAM (2015), “Suriyeli Sığınmacıların Türkiye’ye Etkileri”. Ortadoğu Stratejik Araştırmalar Merkezi, Ocak 2015, https://orsam.org.tr//d_hbanaliz/201518_rapor195tur.pdf (E.T:24 Ocak 2021).

ÖNDER, (2016), “Suriyeli Çocukların Eğitim Sorunu ve Çözüm Önerileri”, 21 Kasım 2016, https://onder.org.tr/tr/Haber/SURIYELI-COCUKLARIN-EGITIM-SORUNU-VE-COZUM-ONERILERI-21-11-2016 (E.T:17 Ocak 2021).

Paksoy, Sadettin ve Mine Karadeniz Özgüven (2017), "Suriyeli Sığınmacıların Kilis Ekonomisine Etkisi", ASSAM, s. 9, ss. 56-79.

Saboohi, Misbah (2018), "Conflict Zones of the Middle East: New Challenges in Search for Durable Solutions for the Arab Refugees", Beijing Law Review, s. 9, ss. 564-581.

Skinner, Jonathan (2012), "A Four-part Introduction to the Interview: Introducing the Interview; Society, Sociology and the Interview; Anthropology and the Interview; Anthropology and the Interview", Jonathan Skinner (ed.), The Interview: An Ethnographic Approach, Londra-New York: Berg Publisher, ss.1-50.

Tanrıkulu, Faik (2017), Önder Rapor 7: Türkiye'de Yaşayan Suriyeli Çocukların Eğitim Sorunu ve Çözüm Önerileri, İstanbul: illke Yayıncılık, https://www.onder.org.tr/Content/pdf/Papers//395988c8-b842-41ff-be19-9b0ea090f9e7.pdf (E.T:17 Ocak 2021).

Uluslararası Göç Örgütü (IOM) (2013), Göç Terimleri Sözlüğü, https://publications.iom.int/ system/files/pdf/iml31_turkish_2ndedition.pdf (E.T: 10 Ocak 2021).

Yardım, Müşerref (2017), “Göç ve Entegrasyon Politikaları Işığında Fransa'da Toplumsal Kabul”, Göç Araştırmaları Dergisi, s. 2. ss. 100-136. 